\title{
Open Adoption and the Politics of Transnational Feminist Human Rights
}

Karen Sotiropoulos

Cleveland State University, k.sotiropoulos@csuohio.edu

Follow this and additional works at: https://engagedscholarship.csuohio.edu/clhist_facpub

Part of the History Commons, Other Social and Behavioral Sciences Commons, and the Sociology Commons

How does access to this work benefit you? Let us know!

\section{Publisher's Statement}

Copyright (C Duke University Press, 2008. This article first appeared in Radical History Review, Volume 101, 2008, 179-90. http://rhr.dukejournals.org/content/2008/101/179.abstract

\section{Repository Citation}

Sotiropoulos, Karen, "Open Adoption and the Politics of Transnational Feminist Human Rights" (2008). History Faculty Publications. 92.

https://engagedscholarship.csuohio.edu/clhist_facpub/92

This Article is brought to you for free and open access by the History Department at EngagedScholarship@CSU. It has been accepted for inclusion in History Faculty Publications by an authorized administrator of EngagedScholarship@CSU. For more information, please contact library.es@csuohio.edu. 


\title{
Open Adoption and the Politics of Transnational Feminist Human Rights
}

\author{
Karen Sotiropoulos
}

Just days after sending off my copyedited manuscript and a week into summer teaching, I received a phone call that changed everything - a call both anticipated and never expected. An African American boy had been born two weeks prior and was waiting for his mother to carry him home. While I had long imagined adopting a baby, I did not foresee how adoptive motherhood would turn my attention to birthmothers' rights, forever deepening my understanding of family, feminism, race, and freedom. Not until I began the adoption home study did I more fully historicize my path to motherhood or contemplate the power relations particular to American adoption practice. I favored open adoption because its insistence on birthmothers' voluntary relinquishment meshed well with my commitment to social justice, but, in the end, racial inequities in adoption and welfare policies helped me (a white woman) adopt my son.

Fortunately a surge in adoption scholarship (much of it written by historians, sociologists, and anthropologists who are adoptive mothers or were themselves adopted as children) has helped me rethink connections among race, child welfare, women's rights, and transnationalism. ${ }^{1}$ In this essay, I want to highlight this scholarship and suggest that paired with the political movement for more openness in adoption, the developing field of adoption studies can pave the way for making adoption a more ethical practice. I hope as well to contribute to the discussion underway of child adoption as a human rights issue by considering together activist trends in domestic and international adoption. Human rights activists and attorneys 
have used the language of human rights both to support and condemn international adoption, while open-records advocates have claimed the right to know one's identity as a human right. Although supporters of open adoption have not usually framed the practice as a question of human rights, their privileging of birthparents' rights is now partly reflected in international law with the 1989 United Nations Convention on the Rights of the Child and the 1993 Hague Convention on Inter-country Adoption. ${ }^{2}$

As one of a growing cohort of professional women in our forties who has chosen single motherhood, I have hardly felt alone in my journey to becoming a parent. In fact, many might see women in this category now known as "single mothers by choice" as de facto feminists based solely on their decision to parent without a man. While I do not want to diminish how much the courageous decision to parent alone challenges the status quo (à la the uproar over the TV character Murphy Brown's pregnancy in the 1990s), I do want to suggest that the category "single mothers by choice" raises a whole host of questions for us to consider. ${ }^{3}$ First, it presupposes that we alone are choosing single motherhood and robs the vast numbers of single mothers (by default?) of agency in their struggle to parent their children. Second, it erases the diversity of parenting choices across class, race, culture, and history, privileging the break we have made from the predominating postwar model of a heterosexual married household. As such, it ignores a time before the rise of state-regulated adoption in the 1920 shen single women were encouraged to adopt - a practice the historian Julie Berebitsky argues upheld rather than challenged gendered expectations locating a woman's ultimate worth in child rearing. ${ }^{4}$ Most important for my concerns here, to postulate the category single mothers by choice as a feminist intervention does little to unveil the politics of the women adopting, or to challenge the lack of adequate child care, paid parental leave, or any other aspect of a social welfare system that has failed to support and has served to demonize (particularly black) single mothers. It is, after all, a language of the marketplace — of "choice," rather than one of rights. ${ }^{5}$ The present-day by-choice moms may be creating a new American family - one that challenges the mythic nuclear-family ideal that reached its height in the baby-boom 1950 - but the transformation is a neoliberal one. Our desire to become mothers actually reflects and reinforces a reformulated pro-natalism that emerged in the 1980 - an ethic that equally marginalizes the childless but that no longer requires that marriage precede parenthood. ${ }^{6}$

Whether by adoption or insemination, by-choice moms - seen as mostly white and upwardly mobile - have taken charge of creating families without marriage, without men. While a human desire to nurture a child underlies these decisions, it is money that helps turn desire into reality - money that can buy kin ties by donor insemination or adoption. And with adoption, a woman's choice to become a mother must be, to use the historian Ricki Solinger's words, "counterweighted by the birthmother's right to be the mother of her child."7 Not unlike in marriage, in 
adoption it is the legal system that finalizes the bond between mother and child, whatever role the heart plays. Birth certificates declare the child as if born to the adoptive parents; they erase the birth parents' existence and take with them the social and historical conditions that made the child available for placement. Fueled largely by Western money and middle-class interests, adoption often pits adoptive parents and birthmothers as adversaries and, in turn, commodifies the human being that forever binds them together. Despite open records and birthmother's rights movements extant since the 1970s, the rights of adoptive parents to "have" a family trump those of either the birthmother or the child in today's legal and social welfare systems. Privileging money over blood, adoption has more often served to contribute to rather than ameliorate the structural inequalities of the child welfare system. ${ }^{8}$ And as Solinger hypothesizes, "the incidence of adoption, that is, the transfer of babies from women of one social classification to women in a higher social classification or group (within the same country or transnationally), may be a very accurate index of the vulnerable status of women in the country of the birthmothers." 9

This picture of a monolithically imperialist adoption industry is of course incomplete. In my own case, it was the agency I worked with that steered me toward open adoption, and it was James Gritter, a Catholic social worker, whose philosophy of candor and openness I found transformative. Gritter charts his move from working with closed records, a period marked by irrevocable pain in separating mother and child, to one of human liberation through "values-based open adoption." His tract, The Spirit of Open Adoption, manages to be both a how-to open-adoption manual and a profound spiritual journey filled with the hope, enlightenment, and love that he believes is attainable by those who confront the pain of separation and loss ever present in adoption. ${ }^{10}$ While it is not his intellectual project to situate the rise of open adoption in its historical context, his elucidation of his experiences and the ethics of open adoption indicate a major shift in American adoption practice. ${ }^{11}$

Yet it is difficult to find much in the way of historicizing this seemingly sudden rise of open adoption in adoption literature, seminars, or classes. While this absence may be due in part to a lack of knowledge, it is also likely related to a desire to cater to an audience of potential adoptive parents, most of whom enter the process simultaneously embracing and fearing the agency of birthmothers. In open adoption, birthmothers hold the power to select the people who will parent their children, as well as the ability to lay out their hopes for a postplacement relationship with their child. Prospective adoptive parents prepare "Dear Birthparent" portfolios advertising themselves to pregnant women. Open-adoption agreements are not in themselves legally binding, however. Birthmothers must relinquish parental rights, a process usually completed within the first few weeks after the child's birth. Once legally surrendering her child, a birthmother has only the good-faith commitment for openness she made with the adoptive parents and with the agency or attorneys handling the adoption. 
The spirit of this extralegal component of an adoption agreement in some ways resurrects an earlier history of adoption in the United States. Legal child adoption is a twentieth-century phenomenon. Born amid Progressive-era reform, it became firmly established in the 1920 with the rise of middle-class markets, the professionalization of social work, changing ideas of nurture over nature, and new attitudes toward unwed mothers. When child welfare workers set up the first private adoption agencies, they were loathe to separate natal families. They saw themselves more as facilitating foster home networks than as permanently placing children in adoptive families. Not unlike many social workers in today's era of openness, Progressive-era child advocates remained committed to connecting adopted children with their birth families. ${ }^{12}$ Perhaps the greatest difference with today, however, is that before World War II, infant adoption was relatively rare, and adoption had little to do with helping infertile couples. The romance with the nuclear family during the baby-boom years and the growing numbers of white middle-class childless couples seeking adoptable infants helped cause this revolution in adoption practice. During these years demand far outstripped supply — market conditions that earned adoption agencies ire from infertile couples gave way to intercountry adoptions and propelled the move to seal records. ${ }^{13}$ Agencies began to cater to adoptive parents who believed that secrecy would eliminate interference from biological parents, a condition that underlay the second phase of child adoption — its boom years — lasting until the early 1970 .

After the passage of Roe $v$. Wade in 1973, increased access to abortion and declining stigma against single motherhood helped inaugurate a third phase of child adoption - one in which fewer single white mothers relinquished their parental rights. Moreover, those white women who chose to place their children did so to intense market demand and during an era rich with rights movements. In this political climate Lee Campbell, a woman who had earlier relinquished a child, formed the first birthmother's rights organization. Campbell was one of a generation of women who had felt coerced into placing their babies for adoption in the 1950 os and 196os due to the then pervasive contempt toward unwed mothers and to pressure from a growing adoption market. In the 1970s, Campbell, by then a married mother of two, published an open letter in the Boston Globe "seeking to correspond with other women who had lost children to adoption." At first she met with other likeminded women under the auspices of the Adoptees' Liberty Movement Association (ALMA) - an organization founded in 1971 by those who had been adopted as children and who had begun to search for their biological roots claiming that it was their birthright to know the truth about their origins. ${ }^{14}$

Although inspired and supported by ALMA, Campbell and the other women who had relinquished children decided to form their own group, Concerned United Birthparents (CUB), in 1976. Campbell reported that the then current term biological parent made them "gag," but since they had no interest in upsetting adoptive 
parents by using the term natural, they compromised by choosing to call themselves birthmothers, a term that had begun to be used by adoption researchers. ${ }^{15}$ CUB focused on "legislation and policy initiatives to enable birthmothers to exchange non-identifying information with adoptive parents; community education and mutual support." Still active today, the organization's mission statement calls for providing support for family members separated by adoption, resources to help prevent unnecessary family separations, education about the lifelong impact on all who are touched by adoption, and advocacy for fair and ethical adoption laws, policies, and practices. ${ }^{16}$

By the 199os, most domestic adoption agencies espoused some amount of openness, and the demand for white infants has allowed white women bearing white children some ability to negotiate placement. It is less clear how much power African American birthmothers have had in placing their children, a distinction that forces a new consideration of the ways in which racial inequities impact adoption practice, child welfare policy, women's rights efforts, and the life circumstances of children of color. The domestic postwar adoption market has not valued black children as it has white ones, and it has not been uncommon for agencies to charge adoptive parents more money for adopting a white child. Sliding scales have sometimes priced a biracial child somewhere in between the price of adopting a white or black child - a hierarchy of fees that unarguably reveals not only the crude and dehumanizing aspects of commercializing child adoption but also how racialized market demands for babies has limited black birthmothers' decision-making power. ${ }^{17}$

Black birthmothers' plight cannot be separated from the longer struggle and disparate history of black women fighting for reproductive freedom, access to health care, and resources for survival. In the 1970s, the National Welfare Rights Organization, not CUB, was working for the interests of black single mothers - a juxtaposition that further illuminates the different rights discourses and imperatives of black and white women. ${ }^{18}$ White women's focus on winning legal abortion tended to ignore black women's struggles to stop sterilization abuse. ${ }^{19}$ And as white birthmothers fought for their individual right to parent their child or to make an adoption plan, they often overlooked the clamor for public welfare entitlements that would enable black women to make health, reproductive, and parenting choices. The post-Roe $v$. Wade and Reagan eras provided some liberation for white middle-class women, but black women remained under intense assault, particularly with the rise of Ronald Reagan's "welfare queen" stereotype, followed shortly thereafter by that of the predatory "crack mother." The rise of open adoption, in fact, coincided with a media spotlight on so-called crack babies. Later medical studies showed no direct correlation between child development and the in utero ingestion of psychoactive drugs, but during the 1980 s and early 199os, stereotypes of black children with untreatable mental illnesses and black birthmother delinquency further limited black agency in child adoption. ${ }^{20}$ Moreover, since prospective adoptive parents are overwhelm- 
ingly white, black birthmothers must also consider the implications of transracial adoption — that is, of placing their children with white parents. And as Dorothy Roberts writes, "Transracial adoption advocates tend to conveniently silence the poor black mothers who fight desperately, without resources and without adequate legal representation, to regain custody of their children from a wealthy and powerful bureaucracy."21

African American birthmothers may actually have more in common with birthmothers abroad who have relinquished children to international adoption - a market that grew significantly during the same years as domestic open adoption. ${ }^{22}$ Solinger intimated this connection when she wrote that domestic and international adoption practices ultimately speak to "the vulnerable status of women in the country of the birthmother." 23 Comparing the circumstances of domestic transracial and international adoption reveals some striking similarities, particularly in the way they have been viewed historically. Faith in international adoption as a solution to inequities in global capitalism has long been a current of U.S. history. Since at least the beginning of the Cold War, prospective adoptive parents looked to Asia and Latin America - and later Eastern Europe - hoping to enrich their lives with other cultures and/or save a child from lifelong poverty. The anthropologist Laura Briggs demonstrates how the politics of rescue and the "adopt-a-child" programs of organizations like UNICEF, CARE, and Save the Children worked alongside international adoption to bolster U.S. public policy on families at home and foreign policy initiatives abroad by playing on imperial themes that sentimentalized women, children, and poverty. ${ }^{24}$ Sometimes the State Department initiated and orchestrated such efforts, as the historian Karen Dubinsky documents with the CIA-backed "Operation Peter Pan" that brought fourteen thousand unaccompanied Cuban children to Miami in the early 1960 s, abandoning thousands of them to the foster-care system. ${ }^{25}$ While adopters and receiving countries have historically viewed such exchanges as rescues, birth communities and sending countries have more often understood child transfer as kidnappings. ${ }^{26}$

This dynamic has appeared as well in the white adoption of African American children; some white liberals, inspired by civil rights activism, sought to create multiracial families in hopes of healing racial wounds. ${ }^{27}$ Some black nationalists in turn insinuated that the white adoption of African American children represented a form of cultural genocide - a belief echoed in the 1972 National Association of Black Social Worker's (NABSW) statement recommending against the practice. As part of the then burgeoning welfare rights movement, the NABSW sought to keep resources in black communities and sustain African-descended families, arguing that black children needed the support of black parents to survive American racism. Its activism succeeded in encouraging domestic adoption agencies to develop racematching strategies, but in 1994, as part of the Clinton-era welfare reform, Congress overrode this imperative by passing the Multiethnic Placement Act (MEPA), which 
penalized agencies for race-matching but did not provide any incentives for the recruitment of black adoptive families. Liberals and conservatives alike have considered MEPA a boon to black children whose long stays in foster care they blamed on a social welfare system bound to an outdated and misguided nationalism.

This act and a series of other laws geared to facilitate (white middle-class) adoptions of (black) children were companions to the 1996 Personal Responsibility and Work Opportunity Act, the bill that ended welfare as we knew it. ${ }^{28}$ This neoliberal attack on civil-rights reform turned Aid to Families with Dependent Children into Temporary Aid for Needy Families, making it even more difficult for poor and working-class women to balance work, education, and family. Moreover, while welfare reform bills gutted public expenditures for poor women, the adoption bills allocated funds to adoptive families through subsidies and tax incentives. If the adopted child had "special needs" — and simply being nonwhite fit this category in most states - adoptive parents could not only recoup some adoption costs but also receive monthly payments until their child reached adulthood. As the Nation columnist Katha Pollitt reported: "A baby who is deemed unworthy of $\$ 64$ a month or $\$ 768$ a year in government support if he stays in his family of origin immediately becomes six times more valuable once he joins a supposedly better-ordered household." Pollitt continued: "Maybe unwed mothers should trade kids." 29 And as the legal scholar Dorothy Roberts concluded, this legislation represented the first time the federal government mandated that states protect children from abuse and neglect with no corresponding mandate to provide basic economic support to poor families. Like marriage advocacy, also a measure emphasized in the 1996 Personal Responsibility Act, the changed adoption legislation was presciently described by Roberts as part of a neoliberal agenda to replace state support with private remedies for social and economic equality. ${ }^{30}$

Even so, white interest in adopting black children did not grow significantly. ${ }^{31}$ Instead, international adoptions continued to increase - whether transracial or not. A shortage of white infants is often given as a primary reason for the escalating demand for international children, raising an eerie question about how domestic racial politics has shaped the value of human beings within and across national borders. But equally as telling, and linked to the rise of open adoption, is the explanation offered by more than a few adoptive parents who explain their choice to adopt internationally as rooted in their desire to avoid birthmothers. ${ }^{32}$ Global markets thus triumphed over the women's rights-inspired move toward openness. Meanwhile, human rights activists have been hard at work seeking to regulate international adoption in response to widespread charges of illegal adoption rings, child trafficking, and kidnapping. ${ }^{33}$ They have had some success in that the 2007 U.S. ratification of the Hague Convention and threats to halt adoption from Guatemala-one of the fastest growing and most controversial markets - compelled the Latin American country to comply with international law. Debates over the proposed ban and 
new rules for compliance have been heated, however, with opponents claiming to be equally concerned with the human rights of impoverished children in need of rescue by U.S. adoptive families. One vocal critic has been the National Council for Adoption - a largely Christian-backed organization long opposed to the movement for open records, arguing that disclosure encourages abortion. ${ }^{34}$

While much more research needs to be done to tell the story of the way women's and human-rights activists have worked together (or at odds) to resist the gross commercialization of adoption at home and abroad, I have come to wonder if there is not a way to internationalize open adoption through legal means or consumer pressure. After all, the UN Convention on the Rights of the Child stipulates that intercountry adoption should enjoy the "safeguards and standards equivalent to those existing in the case of national adoption." 35 Is it possible to engage with the power relationships embedded in the transracial and transnational arenas, whether or not individual birthmothers or birth communities are able to participate in the direct placement of their children? Some white adoptive parents have, in fact, moved in this direction by more fully recognizing the social and historical conditions that made their transracial and/or transnational family possible. They have developed (or deepened) their commitment to their child's birth communities in ways that are qualitatively different from the type of donations some high-profile adoptive parents give to foreign orphanages or to the kind of language and culture courses some adoptive parents seek for their children.

In her study of Latin American adoption, Briggs describes one of the more dramatic examples: the experience of David Kruchkow, who with his wife, Sara, adopted from Mexico only to later learn that the child had not been legally available for adoption. Although Kruchkow was unable to locate his daughter's birth family, he exposed illegalities in adoption practice and criticized the U.S. State Department for ignoring them in a book-length manuscript he published online, When You "Wish upon a Star."36 The Asia scholars Kay Ann Johnson and Toby Alice Volkman both adopted daughters from China, an experience that encouraged them to further research transnational adoption. Along with many other families, they have sought to understand the birth history of their Chinese children, not just the birth culture; some families return to see firsthand the orphanage or roadside where the adoption journey began. ${ }^{37}$ In Weaving a Family, the sociologist Barbara Rothman (a white Jewish woman who adopted an African American girl) writes poignantly of her own evolution in seeing her family through her daughter's eyes. She explains how she came to understand an element of truth in NABSW's intimation that transracial adoption was a kind of genocide after she read that the 1948 International Convention on the Prevention and Punishment of the Crime of Genocide included the "forcible transferring of children of a group to another group" in its definition. Rothman encountered this classification when reading about the "stolen generation" of 
Australian aboriginal children forcibly taken from their homes to be raised in white families in the early twentieth century - a history painfully represented by the 2002 film Rabbit-Proof Fence. ${ }^{37}$ But she wondered whether it was not "forced transfer" as well when women relinquished parental rights due to racism and poverty. ${ }^{38}$

Open adoption is a relatively recent historical phenomenon, so it may be too soon to begin to assess the outcome of this movement in the United States. In the best light, it can be seen as an attempt by birthmothers, social workers, and adoptive families to produce an adoption practice driven more by respect for human rights than by marketplace demands. In practice, there are many stories of letters exchanged, meetings, phone calls, and even visits to attest to the possibility of creating new family relationships enriched by a vast community of blood and adoptive kin. But there are also enough stories — for instance, of birthmothers abandoned by adoptive parents and of social workers misleading birthmothers about future adoptive relationships - to suggest that not all is well with this system, even for white birthmothers. Most of the evidence is highly subjective, and with the stakes so fraught, stories range from overt vitriol to unabashed moralizing. Testimony thus far comes almost entirely from the perspectives of the adults involved; as more adopted children come of age, we will undoubtedly learn more. It is possible, however, that by placing the child's blood ties at the center of their decisions, these families have begun to rewrite the language of Western adoption practice. In doing so, they may be helping remake the face and meaning of family in a way that draws attention to the interconnectedness of child welfare policies around the world and, by extension, to women's human rights struggles.

\section{Notes}

Many thanks to my coeditor "Auntie Mommy" Rhonda Y. Williams for her keen editorial skills that made this essay possible.

1. For example see Julie Berebitsky, Like Our Very Own: Adoption and the Changing Culture of Motherhood (Lawrence: University Press of Kansas, 200o); Laura Briggs, "Making ‘American' Families: Transnational Adoption and US Latin America Policy," in Haunted by Empire: Geographies of Intimacy in North American History, ed. Ann Stoler (Durham, NC: Duke University Press, 2006), 344-65; E. Wayne Carp, Family Matters: Secrecy and Disclosure in the History of Adoption (Cambridge, MA: Harvard University Press, 1998); Ellen Herman, The Adoption History Website, University of Oregon, darkwing .uoregon.edu/ adoption/index.html (accessed August 10, 2007); Kay Ann Johnson, Wanting a Daughter, Needing a Son: Abandonment, Adoption, and Orphanage Care in China (St. Paul, MN: Yeong and Yeong, 2004); Barbara Melosh, Strangers and Kin: The American Way of Adoption (Cambridge, MA: Harvard University of Press, 2002); Sandra Patton, Birthmarks: Transracial Adoption in Contemporary America (New York: New York University Press, 200o); Rickie Solinger, Beggars and Choosers: How the Politics of Choice Shapes Adoption, Abortion, and Welfare in the United States (New York: Hill and Wang, 2001); Jane Jeong Trenka, Julia Chinyere Oparah, and Sun Yung Shin, eds., Outsiders Within: Writing on Transracial Adoption (Cambridge, MA: South End Press, 20o6); Toby 
Alice Volkman, ed., Cultures of Transnational Adoption (Durham, NC: Duke University Press, 2005); Barbara Yngvesson, "Negotiating Motherhood: Identity and Difference in 'Open Adoptions,'” Law and Society Review 31 (1997): 31-80.

2. International and intercountry are used here to refer to the adoption market; transnational names the relationships and identities formed. For the open records movement, see E. Wayne Carp, Adoption Politics: Bastard Nation and Ballot Initiative 58 (Lawrence: University Press of Kansas, 2004); Bastard Nation, www.bastards.org (accessed August 20, 2007); Americans for Open Records, www.amfor.net (accessed August 20, 2007).

3. Now a national organization, Single Mothers by Choice was founded in 1981 by Jane Mattes. Scholarly work includes Jane D. Bock, "Doing the Right Thing? Single Mothers by Choice and the Struggle for Legitimacy," Gender and Society 14 (2000): 62-86; Rosanna Hertz, Single by Chance, Mothers by Choice: How Women Are Choosing Parenthood without Marriage and Creating the New American Family (New York: Oxford University Press, 2006).

4. Berebitsky, Like Our Very Own, 75-76.

5. Solinger, Beggars and Choosers, 96; Barbara Rothman, Weaving a Family: Untangling Race and Adoption (Boston: Beacon Press, 2005), 35-36.

6. Elaine Tyler May, Barren in the Promised Land: Childless Americans and the Pursuit of Happiness (Cambridge, MA: Harvard University Press, 1995), 129-213.

7. Solinger, Beggars and Choosers, 96 .

8. Dorothy Roberts, Shattered Bonds: The Color of Child Welfare (New York: Basic Books, 2002); Laura Briggs, “Orphaning the Children of Welfare: 'Crack Babies,' Race, and Adoption Reform," in Trenka, Oparah, and Shin, Outsiders Within, 75-88.

9. Solinger, Beggars and Choosers, 67.

10. James L. Gritter, The Spirit of Open Adoption (Washington, DC: Child Welfare League of America, 1997), 8.

11. The journalist and adoptive father Adam Pertman discusses this shift in Adoption Nation: How the Adoption Revolution is Transforming America (New York: Basic Books, 200o); See also Carp, Family Matters, chap. 7.

12. Berebitsky, Like Our Very Own, 35-36; Carp, Family Matters, 15-18, 222, 230; Melosh, Strangers and Kin, 3-4, 15-21.

13. Carp, Family Matters, 28-35; Melosh, Strangers and Kin, 3-4, 15-21.

14. Carp, Family Matters, 196, 204; Melosh, Strangers and Kin, 277-78; Solinger, Beggars and Choosers, 81.

15. Solinger, Beggars and Choosers, 105; Carp, Family Matters, 149; Melosh, Strangers and Kin, 240.

16. The quotation is from Solinger, Beggars and Choosers, 105; Concerned United Birthparents Web site, www.cubirthparents.org (accessed August 10, 2007).

17. Christine E. Edwards and Christine L. Williams, "Adopting Change: Birth Mothers in Maternity Homes Today," Gender and Society 14 (2000): 167; Heather M. Dalmage, "Interracial Couples, Multiracial People, and the Color Line in Adoption," in Adoptive Families in a Diverse Society, ed. Katarina Wegar (New Brunswick, NJ: Rutgers University Press, 2006), 212.

18. See for example Premilla Nadasen, Welfare Warriors: The Welfare Rights Movement in the United States (New York: Routledge, 2005); and Rhonda Y. Williams, The Politics of Public Housing: Black Women's Struggle for Urban Equality (New York: Oxford, 2004), chap. 6. 
19. Jennifer Nelson, Women of Color and the Reproductive Rights Movement (New York University press, 2003); Dorothy Roberts, Killing the Black Body: Race, Reproduction, and the Meaning of Liberty (New York: Pantheon, 1997); Johanna Schoen, Choice and Coercion: Birth Control, Sterilization, and Abortion in Public Health and Welfare (Chapel Hill: University of North Carolina Press, 2005).

20. Laura Briggs, "Orphaning the Children of Welfare," 75-88; Anne Collinson, "The Littlest Immigrants: Cross-Border Adoption in the Americas, Policy, and Women's History," Journal of Women's History 19, no. 1 (2007): 132-41; Patton, Birthmarks, 130-67.

21. Dorothy Roberts, "Adoption Myths and Racial Realities in the United States," in Trenka, Oparah and Shin, Outsiders Within, 55.

22. Native American women figure prominently in this history as well, but space does not allow a discussion here.

23. Solinger, Beggars and Choosers, 67; my emphasis.

24. Laura Briggs, "Mother, Child, Race, Nation: The Visual Iconography of Rescue and the Politics of Transnational and Transracial Adoption," Gender and History 15 (2003): 179-200.

25. Karen Dubinsky, "Babies without Borders: Rescue, Kinship, and the Symbolic Child, Journal of Women's History 19, no. 1 (2007): 143, 147.

26. Elizabeth Bartholet has been the most prominent advocate of "rescue" in transracial and transnational adoption. See her Family Bonds: Adoption and the Politics of Parenting (Boston: Houghton Mifflin, 1993), chaps. 6 and 7; and Nobody's Children: Abuse and Neglect, Foster Drift, and the Adoption Alternative (Boston: Beacon, 1999); Briggs, "Making 'American' Families," 346; Solinger, Beggars and Choosers, 29-32; Barbara Yngvesson, "Un Nino de Cualquier Color': Race and Nation in Inter-country Adoption," in Globalizing Institutions: Case Studies in Regulation and Innovation, ed. Jane Jenson and Boaventura de Sousa Santos (Burlington, VT: Ashgate, 2000), 182-83.

27. Dubinsky, "Babies without Borders," 142-44; Melosh, Strangers and Kin, 158-59.

28. Ana Teresa Ortiz and Laura Briggs, "The Culture of Poverty, Crack Babies, and Welfare Cheats: The Making of the 'Healthy White Baby Crisis,"' Social Text, no. 76 (2003): 48-49: Patton, Birthmarks, 2-4, 22-24, 50, 140-42, 155; Roberts, Shattered Bonds, $164-69$.

29. Katha Pollitt, Nation, July 8, 1996, 9. See also Briggs, "Orphaning the Children of Welfare," 75-88; Yngvesson, "Negotiating Motherhood," 39-40.

30. Roberts, "Adoption Myths," 53.

31. The percentage of African American children placed in adoptive families from foster care dropped from 44 percent in 1997 to 35 percent in 2001. Ibid.

32. Anita M. Andrew, "China's Abandoned Children and Transnational Adoption," Journal of Women's History 19, no. 1 (2007): 124; Collinson, "Littlest Immigrants," 133-35; Solinger, Beggars and Choosers, 31.

33. Briggs, "Making 'American' Families," $35^{8-61}$

34. The National Council for Adoption, "Department of State Announcement Puts Children Waiting in Guatemalan Foster Care at Risk," March 14, 2007, www.adoptioncouncil.org; Carp, Family Matters, 67-68; "New Guatemala Adoption Law Approved," New York Times, December 11, 2007; "US Families Race to Adopt from Guatemala," New York Times, December 12, 2007.

35. Ellen Herman, The Adoption History Project, University of Oregon, darkwing.uoregon .edu/ adoption/index.html (accessed August 10, 2007). 
36. Briggs, "Making 'American’ Families," 351-52; David N. Kruchkow, "When You Wish upon a Star: An Adoption Story," The Adoption Agency Checklist, www.adoptionagencychecklist .com/page655.html (accessed December 11, 2007).

37. Johnson, Wanting a Daughter; Volkman, "Embodying Chinese Culture: Transnational Adoption in North America," in Cultures of Transnational Adoption, 81-113; Emily Prager, Wuhu Diary: On Taking My Adopted Daughter Back to Her Hometown in China (New York: Random House, 2001).

38. Rabbit-Proof Fence, dir. Philip Noyce, Australia, 2002

39. Rothman, Weaving a Family, 103-6. 